\title{
Тувинская национальная поэзия 30-40-х годов XX века
}

\author{
Людмила С. Мижит \\ Тувинский институт гуманитарных и прикладных социально-экономических исследований \\ при Правительстве Республики Тыва, Российская Федерация
}

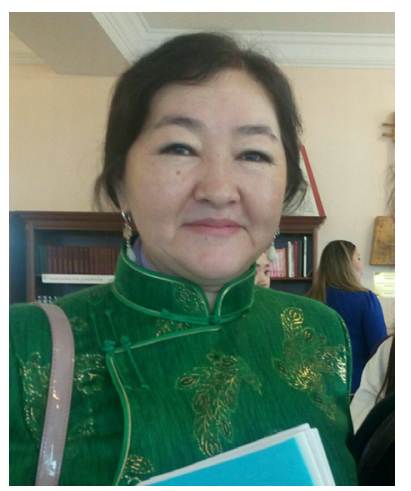

В статье анализируются первые два десятилетия становления тувинской поэзии (1930-1940-х г2.). Разбираются тексты сборников произведений поэзии тех лет, привлекаются архивные материалы Тувинского института гуманитарных и прикладных социально-экономических исследований.

В первую очередь поэзия опиралась на традиции народного устно-поэтического творчества, а также формировалась под влиянием русской, советской поэзии (приемы стихосложения, способы построения художественных образов, развития и углубления поэтической мысли, идейное содержание и т. д.). Наряду с Сергеем Пюрбю и Степаном Сарыг-оолом, фундамент письменной тувинской поэзии закладывали: Монгуш ИдамСюрюн, Байкара Ховенмей, Леонид Чадамба, Салчак Самба-Люндуп, Салчак Тамба, Александр Тамба-Сюрюн, Василий Эренчин.

В 1940-е годы тувинская поэзия обрела свой неповторимый облик, заключающийся в национальной самобытности, гуманистическом пафосе борьбы за справедливость, светлое будущее и возвышение человека новой эпохи. Появились первые зрелые, знаковые произведения, ставщие классикой тувинской литературы: поэмы «Чечек» С. Пюрбю и «Саны-Мөге» С. Сарыг-оола. Так, были созданы крепкие основы гражданской, лирической и эпической поэзии Тувы.

Ключевые слова: Тувинская Народная Республика; история Тувы; история литературы; Тува; тувинская поэзия; тувинская литература; тувинский язык; яналиф

Мижит Людмила Салчаковна - кандидат филологических наук, ученый секретарь Тувинского института гуманитарных и прикладных социально-экономических исследований при Правительстве Республики Тыва. Адрес: 667000, Россия, г. Кызыл, ул. Кочетова, д. 4. Тел.: + 7 (963) 252-34-09. Эл. адрес: lmizhit@mail.ru

MIZHIT, Lyudmila Salchakovna, Candidate of Philology, Academic Secretary, Tuvan Institute of Humanities and Applied Social and Economic Research under the Government of the Republic of Tuva. Postal address: 4 Kochetov St., 667000 Kyzyl, Russian Federation. Tel.: 7 (963) 252-34-09. E-mail: lmizhit@mail.ru 


\title{
Tuvan national poetry in the 1930 s and 1940s
}

\author{
Lyudmila S. Mizhit \\ Tuvan Institute of Humanities and Applied Social and Economic Research \\ under the Government of the Republic of Tuva, Russian Federation
}

The article examines the first two generations of Tuvan poetry - 1930s and 1940s, with a focus on the texts of collections of poetry published over that time and archival materials preserved at the Tuvan Institute of Humanities and Applied Social and Economic Research.

Tuvan poetry was born in the 1930s after the creation of the national writing system and was based on the folk and ethnocultural traditions of the people, mainly on folk songs. It was also seriously influenced by the Russian and Soviet poetry of that period, especially in composition, creating poetic imagery, complicating poetic thought and providing ideological background. Along with Sergey Pyurbyu and Stepan Saryg-ool, other pioneers who laid the foundation of written Tuvan poetry were Mongush Idam-Syuryun, Baykara Hovenmey, Leonid Chadamba, Salchak Samba-Lyundup, Salchak Tamba, Alexander Tamba-Syuryun, and Vasily Erenchin.

In the 1940s Tuvan poetry developed a unique voice of its own, which combined a distinctive ethnic character, a humanist drive towards justice, bright future for all and a new man of a new epoch. The first works of Tuvan literature to reach the status of a classic were S. Pyurbyu's poem "Chechek" and S. Saryg-Ool's poem "Sany-Mege". They formed the basis of the future lyrical, epic and civil poetics of Tuvan literature.

Keywords: Tuvan People's Republic; history of Tuva; history of literature; Tuva; Tuvan poetry; Tuvan literature; Tuvan language; yanalif

\section{Введение}

1930-1940-е годы в Тувинской Народной Республике (далее - ТНР) - это время радикальных, коренных перемен в обществе, ломки традиций и переоценки ценностей. Этническая духовная культура стала считаться пережитком прошлого. Первые революционные песни, стихотворения и одноактные спектакли пробуждали непоколебимую веру народа в социалистические идеи и в то, что строится настоящее, правдивое и справедливое общество.

В связи с этим поэтические произведения периода ТНР нами рассматриваются в контексте с теми социально-культурными явлениями, на фоне которых они создавались. Как отмечает В. Е. Хализев, при контекстуальном изучении произведения «...литературовед (подобно любому другому читателю) обречен воспринимать создания прошлых эпох прежде всего глазами своей современности, которая, как уже говорилось, переакцентуирует, видоизменяет и достраивает давние художественные творения. В то же время интерпретатор произведения призван осмыслить сотворенное ранее как феномен того времени» (Хализев, 2009: 292; курсив источника. - Л. М.). А по заключению А. В. Михайлова, заача исследователя состоит в том, чтобы осуществлять «обратный перевод» рассматриваемых произведений на культурный язык того времени (Михайлов, 2000: 16).

Самым первым произведением тувинской литературы принято считать стихотворение «Lenin-u tukhai shiluglel»1 («Стихотворение о Ленине», 1926 г.), написанное партийным работником М. Содуна-

\footnotetext{
${ }^{1}$ Sodnam. Lenin-u tukhai shiluglel // Khuviskaalt ard (журнал). 1926, № 2. Ar. 45. (На монг. яз.).
} 
мом на монгольском языке (Куулар, 1970: 15). 30 марта 1929 г. в газете «Erkhe cholootei bukhu Tuva» («Свободная Тува») опубликовано стихотворение Д. Барыкаан «Martyn naim» («Восьмое марта») на монгольском языке.

Ключевым событием периода ТНР стало создание национальной письменности на основе латинского алфавита (единого тюркского алфавита яналиф) в 1930 г. (Татаринцев, 2005: 17-20)2. Вслед за этим, на страницах местных газет, выходивших с 1920-х годов на монгольском языке (на старомонгольской письменности), стали появляться стихотворения на родном языке первых певцов нового строя: Сарыг-оола «Эрге-шөлээ бисте турда» («Когда у нас права и свобода») - о братской помощи СССР тувинскому народу, «Херээжен» («Женщина») - о женской доле в дореволюционной Туве, «Бис тиилээн бис» («Мы победили») - о страданиях тувинских аратов до Октябрьской революции и «взошедшем новом солнце»; Ховенмея: «Хостуг арат билип тур, оо» («Свободный арат внимает»), «Октябрьның тугу» («Знамя Октября») - о событиях не только в Туве, но и в СССР (см.: Тыва совет ..., 1975: 16). С 1934 г. авторами поэтических строк стали также Пюрбю: «Барыын чүктен үнген хүн» («Солнце, взошедшее с Запада»), «Эш херээжен» («Товарищ женщина»); Самба-Люндуп: «Тайбың» («Мир»), «Колхоз оруун шилип алдым» («Я выбрал путь колхоза») и др., которые публиковались в газетах тех лет (Танова, 2013: 26, 38). В указанное время преобладала публицистическая поэзия, имеющая ярко выраженную идеологическую направленность. Вышеуказанные авторы стали первыми шүлүкчүз (стихотворцами) зародившейся тувинской поэзии.

В данной статье ставится цель проследить первые шаги тувинской поэзии, воспевавшей новый этап в жизни народа по требованиям идейно-политических и морально-этических установок власти той эпохи. Соответственно решается ряд задач. Рассмотрены два этапа развития поэзии - в 1930-е и 1940-е годы, имеющие свои особенности, и отдельно проанализировано раннее творчество основоположников тувинской поэзии. Использованы историко-культурологический и аналитический методы исследования.

Источниковую базу статьи составляют сборники произведений поэзии 1930-1940-х годов, а также литературоведческие труды сотрудников Тувинского научно-исследовательского института языка, литературы и истории (ТНИИЯЛИ), ныне - Тувинского института гуманитарных и прикладных социально-экономических исследований при Правительстве Республики Тыва (ТИГПИ) (Тыва литератураның ..., 1953; Тыва литература: ..., 1964; Куулар, 1970; Тыва совет ..., 1975; Калзан, 1980; История тувинской ..., 2013), также привлекаются архивные материалы данного института.

\section{Тувинская поэзия 1930-х годов}

Все выходившие в периодической печати стихи и песни того периода были изданы в первом литературном сборнике «Сььndь cogaaldar» ${ }^{4}$ («Сборник произведений») на тогдашней тувинской письменности, основанной на латинице (яналиф), в 1937 г. Это был первый результат творческой деятельности тувинских авторов в 1930-х годах. Составителем и ответственным секретарем выпуска является Оччурбанак 5 . В своем предисловии он написал, что некоторые авторы выдают народные песни за свои стихи и привел следующий пример:

Elezinnig Temir-le-sug

Estep xadop codbr-la-pe,

Ezir kuuş-teo cyolyg polza,

Ergij kergeş kelgen polza.
Лежит ли песчаный Демир-Суг без изменений,

Пески свои взметая ввысь на ветру,

Вот если б имел орлиное я оперение, Облетел бы и оглядел все вокруг.

(Agbaan)

(Пер. Э. Мижита)

${ }^{1}$ Parykaan. Martyn naim // Erkhe cholootei bukhu Tuva (газета). 1929. 30 марта. Ar. 4. (На монг. яз.).

${ }^{2}$ На кириллицу тувинская письменность перешла в 1943 г.

${ }^{3}$ Шүлүкчү - стихотворец, от слова шүлүк - стихотворение. Является заимствованием из монгольского языка (ср. монг. шүлэг), принятым в Туве в 1934 г. «по решению литературного кружка и с одобрения Ученого комитета» (Куулар, 1970: 21).

${ }^{4}$ Сььndь cogaaldar [Сборник произведений] (1937). Pir tugaar yndyrgeni. Кьzьl : Cogaal komitedi. 194 ar. (Ha тув. яз.).

${ }^{5}$ В современной орфографии - Очурбаанак.

${ }^{6}$ Подстрочный перевод стихотворений на русский язык здесь и далее - Э. Мижита. 
Действительно, по структуре и стилю угадывается народная песня. Как утверждает Очурбаанак, это была песня аратов села Темир-Суг Улуг-Хемского кожууна ${ }^{1}$.

Сборник открывается текстом песни «Internasional» («Интернационал»), видимо, коллективного сочинения. Далее следуют стихотворения следующих авторов: Сарыг-оол (Sarbq-ool) ${ }^{2}$ «Ekki curttuвus xolubusta, erge şөleeвis podususta» («Хорошая страна - в руках наших, свобода наша - у нас самих»); Хөвеңмей (Хөвепmеј) «On aldь сьldьn iştinde» («В течение 16 лет»), «Xostuণ arat pilip tur, оо» («Свободный арат внимает»), «Oktaвrnьn odu kapitalistarnь oja cidi» («Огонь Октября разъедает капиталистов»); Пүрбү (Ругву) «AREVЭ³ telgerezin!» («Да здравствует Ревсомол!»), «Oktaвr» («Октябрь»), «Am-taa tiileeli» («Еще будем побеждать»), О. Торжу (O. Torzu) «Tagьn kattap tarlatpas-pis» («Больше не дадим себя порабощать»). Последнее стихотворение стало одной из самых распространенных революционных песен того времени. В те годы все сочиненные стихи пелись под народные мелодии.

Следующий раздел книги «Puşkinnin elge-le 100 cbl polgan ojun taвarıştbr orus tbldan occuldurgan şylykter» («Стихотворения Пушкина, переведенные с русского языка, к 100-летию со дня его смерти») состоит из прозвучавших на тувинском языке творений А. С. Пушкина: «Turaskaal» («Я памятник себе воздвиг нерукотворный...», пер. Пюрбю), «Cadaefke» («К Чаадаеву», пер. Токи), «Siвir-ce» (пер. Сарыгоола), «Xajaalıg xyn telgerezin!» (пер. Лопсана). А завершается раздел стихотворным приложением от имени тувинского общества в связи с годовщиной трагической гибели Пушкина «Aldьn xyn poop cьrьp tur» («Светится золотым солнцем»).

Рассматриваемый нами сборник первых стихотворений и переводов тувинской литературы представляет собой книгу довольно внушительного объема (194 стр.), объединяющую большое количество лиц, интересовавшихся стихотворчеством. Но из 45 человек, опубликовавших свои первые опыты в этом сборнике, лишь четверть осталась на ниве тувинской литературы: Сарыг-оол (впоследствии Степан Сарыг-оол), Пүрбү (Сергей Пюрбю), Көк-оол (Виктор Көк-оол) , Идам-Сүрүн (Монгуш ИдамСюрюн), Самба-Лүндуп (Салчак Самба-Люндуп), Хөвеңмей (Байкара Ховенмей), Эренчин (Василий Эренчин), Тамба (Салчак Тамба) и другие.

В 1939 г. вышел в свет второй выпуск этого сборника, включавший не только стихотворения начинающих авторов, но и популярные в те годы песни и записанные у носителей народной мудрости пословицы, загадки и сказки ${ }^{4}$ Как писал А. К. Калзан, в 1930-х годах характерным для поэтической речи было использование народного языка в несколько модифицированной, литературной манере (Калзан, 2005: 132).

На формирование поэзии особое влияние оказали художественные особенности устно-поэтической речи: гармония гласных, аллитерация, анафорическое созвучие слов, тавтология и т. д. Зачинатели тувинской поэзии, творчески перерабатывая и совершенствуя художественно-поэтический строй народных песен и припевок, их ритмико-синтаксическую структуру, заложили фундамент новой письменной поэзии. Только нужно было внести новое содержание, новый революционный дух.

Народные романтически-лирические песни в годы перестройки сознания переделывались в декларативно-лозунговые. В песнях появились, хоть и резали слух и ритмически плохо ложились в строку, иностранные слова - «интернационал», «пролетарий», «октябрь», «революция», «культура».

Одним из первых учителей для начинающих авторов был известный исследователь тувинского языка, переводчик А. А. Пальмбах. Его авторское стихотворение «Tarlatkan ulustarnь reвolus xostaan» («Революция освободила угнетенных») написано в 1932 г. как поиск новых средств для зарождающейся тувинской поэзии - по рифмовке русского стиха. Нехарактерный для тувинской поэтической традиции прием принят как опыт творческих исканий.

Интересен тот факт, что первые опыты написания стихотворений были коллективными - их сочиняли ученики пунктов по ликвидации безграмотности. По образцу народной песни слагались новые, переделанные строки, отражающие идеи новой эпохи (Куулар, 1970: 17-18). Первые книги и хрестоматии «Picii turguzukcular» 1931 г., «Pistin azbl» 1934 г., «Өөreniili» 1936 г., «Caa oruk» 1938 г. изобиловали стихотворениями и песнями коллективного сочинения.

\footnotetext{
${ }^{1}$ Сььndь cogaaldar [Сборник произведений] (1937) Pir tugaar yndyrgeni. .... Аp. 7. (На тув. яз.).

${ }^{2}$ Традиционно тувинцы имели только имена (без фамилий и отчеств), а для уточнения или если имена совпадали, добавляли название рода.

${ }^{3}$ Аныяктарның революстуг эвилели - Революционный союз молодежи (Ревсомол).

${ }^{4}$ Сььndь cogaaldar [Сборник произведений] (1939). Iji tugaar yndyrgeni. Кьzьl: Cogaal komitedi. 158 ar. (На тув. яз.).
} 
Подобное явление было характерно почти для всех национальных литератур Сибири того времени. О таких «песнях-переделках» пишут известные исследователи бурятской литературы В. Ц. Найдаков и Г. О. Туденов: «Иногда замена только отдельных слов и стихов давала разительные результаты - такова природа устной импровизации (в 1920-х годах. - Л. М.). Например, в ёхорных песнях и частушках обновление одних припевок поднимало идейно-политический уровень всего цикла» (История бурятской ..., 1995: 132). Так же обстояло дело с первыми поэтическими опытами хакасских авторов, которые «сохраняли внешнюю структуру тахпаха и его традиционные художественные приемы: параллелизм, образ-сравнение, аллегорию» (Очерки истории ..., 1985: 16-17).

Следует подчеркнуть, что в 1930-х годах основу тувинской поэзии составляли преимущественно революционные песни с пафосом утверждения нового строя. Как верно отметила относительно якутской литературы 1920-1930-х годов Л. Н. Романова, «существующая власть в целом выбрала верную, беспроигрышную тактику по отношению к литературе, сделав ее своим орудием, проводником, глашатаем лозунгов, являвшихся, по сути, политической программой, безоговорочно подчиняющей себе сознание масс» (Литература Якутии ..., 2005: 104). В конце 1930-х годов появились сатирические песни и стихи на злободневную тематику, как и в импровизированных пьесах, высмеивающих феодалов, лам и шаманов, которые имели немаловажное значение для культурной революции тех лет (Куулар, 1970: 37).

В становлении тувинской поэзии огромную роль сыграло творчество русских поэтов, особенно А. С. Пушкина и В. В. Маяковского. 11 февраля 1937 г. в газете «Аревэ шыны» («Правда ревсомола») вышла литературная страница, посвященная 100-летию со дня гибели А. Пушкина, и переводы его стихотворенийํ․ 13 февраля 1937 г. в клубе им. Шагдыр-Сюрюна состоялось собрание общественности г. Кызыла, где тувинский народ впервые услышал о Пушкине из доклада А. Пальмбаха. Собрание приняло обращение к читателям республики: «изучать и пропагандировать творчество Пушкина и сделать произведения великого поэта оружием борьбы с пережитками прошлого в жизни тувинского народа»². «Пушкинские дни», проводимые с целью ознакомления с творчеством великого русского поэта, сыграли значительную роль в развитии и совершенствовании тувинской поэзии.

Переводя произведения Пушкина на тувинский язык, первые тувинские писатели узнавали новые методы, размеры, изобразительные средства поэзии, что позволило им использовать в своих стихотворениях элементы жанрового и формального своеобразия русской поэзии. В частности, успешно заимствовали знаменитую «лесенку» Маяковского, усиливая художественную значимость интонации, что обогатило идейный пафос и экспрессию произведений. Число строк в строфе увеличилось до шести, восьми. «Опыт В. Маяковского впервые внес в тувинскую поэзию С. Пюрбю - в стихотворении “Чалыы назынның кылажы” (“Шествие юности”)» (Тыва литература, 1964: 98).

Таким образом, зарождающаяся в 1930-х годах тувинская поэзия, во-первых, опиралась на традиции народного устно-поэтического творчества, во-вторых, благодаря наставнической деятельности А. А. Пальмбаха и переводам произведений русских и советских поэтов, старалась вобрать в себя все то новое, что впоследствии сыграло огромную роль в ее становлении. Это не только формальные приемы стихосложения, но и способы построения художественных образов, развития и углубления поэтической мысли, идейного содержания и т. д. И эти две опоры предопределили ход и направление развития молодой тувинской поэзии на многие годы вперед.

\section{Основоположники тувинской поэзии}

Одним из зачинателей тувинской поэзии, теоретиком и практиком литературы своего времени является Сергей Пюрбю (1913-1975). В те годы все его публикации выходили под его исконным именем - Pyrby (с 1943 г. - Түлүш Пүрбү; после всеобщей паспортизации граждан Тувы в 1947 г., связанной с вхождением Тувы в состав СССР в 1944 г., ввиду того что в русском алфавите нет буквы «ү», в паспорте написали «Пюрбю». Имя стало фамилией, а новое имя - Сергей). Первый сборник стихов Пюрбю вышел в свет в 1944 г. под названием «Эртенгиниң ыры» («Песни утра»). В 1939 г. он написал брошюру «Аныяк чогаалчыларга дуза» («В помощь молодым писателям»). Это был первый опыт литературно-критического труда - теоретическая разработка вопросов тувинской литературы

${ }^{1}$ Aldın xyn poop сьrьp tur [Светится золотым солнцем] // Arevэ şьnь (газета). 1937. Февраль 11. Аr. 2. (На тув. яз.)

${ }^{2}$ Şьn (газета). 1937. Февраль 13. Ar. 2. (На тув. яз.) 
на основе трех родов литературы, введение терминологического аппарата, жанровых понятий и т. д., призванная обучать начинающих авторов азам литературного творчества.

Лиро-эпическая, реалистическая поэма С. Пюрбю «Сеccek» (имя героини Чечек, букв. - ‘цветок’), вышедшая в свет в 1941 г. ${ }^{1}$, «стала вершиной тувинской поэзии того времени и ознаменовала ее переход на новый уровень развития» (Куулар, 1970: 38). Автор воссоздает панораму драматической истории тувинского народа в дореволюционной Туве, радикальных изменений в обществе с установлением советской власти и формирования нового типа личности на примере судьбы главной героини поэмы Чечек. Данное произведение С. Пюрбю прочно занимает свое достойное место в «золотом фонде» тувинской литературы.

Одним из основоположников тувинской литературы является также Степан Сарыг-оол (1908-1983). Первые стихотворения С. Сарыг-оола, как и у всех первопроходцев, печатались на основе латинской графики. Из стихотворения «Aas-kezii» («Счастье»):

Arat namnon salgakcbzb-

AREVEge kirip algaş,

Azbol, pagaj совиlandan

Adaanbm ap, xbbm xangan ${ }^{2}$.
Вступив в АРЕВЭ,

В ряды наследника народной партии,

Горькому и тяжкому страданию

Отомстив, я удовлетворен.

Одним из ярких достижений тувинской поэзии периода ТНР является поэма Степана Сарыг-оола «Саны-Мөге» (имя лирического героя), опубликованная в 1943 г. Произведение представляет собой лирико-публицистический монолог старика-тувинца о своей жизни - о тяжелом детстве, страданиях его родителей, борьбе за достойное существование, о сложной, противоречивой картине революционной эпохи. Проявлением новаторства поэта для своего времени, на наш взгляд, является глубина проникновения в психологическое состояние героя. Данное произведение старейшины тувинской поэзии С. Сарыг-оола основательно исследовано в очерках по истории тувинской литературы Ю. Ш. Кюнзегешем и А. К. Калзаном (Тыва литература, 1964: 91-95; Тыва совет литератураның ..., 1975 : $69-70,240-243)$ и вошло в сокровищницу тувинской литературы.

Наряду с С. Пюрбю и С. Сарыг-оолом, создавали основу письменной тувинской поэзии немало первопроходцев: Байкара Ховенмей (1915-1972), Леонид Чадамба (1918-1987), Салчак Самба-Люндуп (1916-1981), Салчак Тамба (1918-1983), Александр Тамба-Сюрюн (1914-1971), Василий Эренчин (1912-1961). Эти писатели были первыми членами Союза писателей ТНР, созданного в 1942 г., авторами первых стихотворений тувинской литературы. Они были одними из самых известных, прогрессивно мыслящих людей своего времени, которые первыми обучились тувинской письменности, стали учителями в кружках по ликвидации безграмотности, а также одними из первых выучивших русский язык и осуществлявших переводы. Они издавали первые учебники, хрестоматии, сборники, работая в книжном издательстве, типографии или редакциях газет. Примерно такой же путь прошли и первые писатели других регионов Сибири, например, Алтая: М. В. Мундус-Эдоков, П. А. Чагат-Строев (История алтайской ..., 2004: 161).

Следующим поэтом, оставившим яркий след в истории зарождения тувинской поэзии, является Монгуш Идам-Сюрюн (1920-1970). Он начал печататься с 1939 г. Был репрессирован по ложному обвинению вместе с Сергеем Пюрбю в 1948 г.

М. Идам-Сюрюн одним из первых стал посвящать стихи тяжелому историческому прошлому тувинцев. Например, написанные в 1940 г. следующие выстраданные строки М. Идам-Сюрюна заставляют читателя представить, насколько страшным и безвыходным было положение тувинского народа в XIX - начале XX в.:

\footnotetext{
${ }^{1}$ Pyrby. Ceccek (şylyglel) // Revolustun xereli. 1941, № 1. Ar. 28-24. (На тув. яз.)

2 Далее стихи переложены на кириллицу.
} 
Эзээргектиң дужу турда, арат

Эрге-медел, амыр-чыргал турган КИЖЭЭ

Эргим чурттуң ужу-кыдыын каяа эвес.

Эрии-шаагай чаңгыланып эдип

Төөгұден чурук ышкаш көрүп чор

$$
\text { чедир }
$$$$
\text { чорду. }
$$

Төгұлген хан Тере-Хөл дег хөл-даа

$$
\text { бuc, }
$$

болур.

Бабк холдан өлген чонну чыыр

Бай-Даг ышкаш хорумналган даг-

болза, даа болур.

Дорамчылал, кинчи-бектер даг дегдаа бол,

Довук дег ак доозазын ширбип

каапкан.

Тываларның өскен чуртун чыргал

хүннээн,

Тынып чорда таан таптыг, шөлээн

болган.
Разве право имел и разве счастье

Когда было время тирановвидел арат, самодуров.

Ведь во всех пределах родимой страны

Звуки пыток и казней вовсю звучали.

Мы историю, словно картину, всю видим,

Вся пролитая кровь может стать озером, как озеро Тере-Холь.

Если собрать народ, погибший от проклятых рук,

Может образоваться гора, величиною с гору Бай-Даг.

Пусть велики, как гора, униженья и

цепи,

Белизна с коленную чашечку их победила и вымела вон.

Блаженство солнцем осветило родную землю тувинцев, И стало свободно, и дышится здесь так легко.

Свое видение и оценку данного события автор выразил в метафорической строке «Аккан ханы тугум болган» - «Пролившаяся их кровь стала знаменем моим», ставшей его размышлением и душевными переживаниями о прошлом и радостью о «настоящем счастье» народа.

Можно отметить как художественное достижение тувинской поэзии 1930-1940-х годов следующие стихотворения М. Идам-Сюрюна: «Фронтучуларга» («Фронтовикам»), из любовной лирики: «Оолдуң чагаазы» («Письмо парня»), «Сагыжымдан дүне, хүндүс ыравадың...» («И днем, и ночью ты в мыслях моих...»), а также «Аныяк дииңчиге» («Молодому охотнику»), «Улуг-Хем дугайында ыры» («Песня о Енисее»), «Кара-Сугга» («Речке Кара-Суг») ${ }^{1}$. Эти стихи выделяются особым, несомненным лирическим чувством и эстетическим мастерством среди произведений большинства авторов того периода. В его стихах меньше повторений идеологических лозунгов, а такие строки, как «Пусть велики, как гора, униженья и цепи, / Белизна с коленную чашечку их победила и вымела вон», трогают читателя эмоционально заряженной образностью, что является признаком подлинной поэтической речи.

Начало поэтического творчества основоположников - будущих классиков тувинской литературы С. Пюрбю и С. Сарыг-оола, а также незаслуженно забытого в связи с его репрессией вместе с С. Пюрбю в 1940-х годах, одного из талантливых поэтов своего времени М. Идам-Сюрюна - характеризуется выработкой новой эстетики, реалистического стиля, активным поиском и освоением новых для мировоззрения тувинцев-кочевников тем, форм, образов и мотивов для освещения новой, невиданной для тувинца общественной формации. В произведениях этих писателей, а именно в поэмах «Чечек» С. Пюрбю, «Саны-Мөге» С. Сарыг-оола, «Үделге» М. Идам-Сюрюна, налицо достижение нового уровня поэтического мастерства: больше ярких эпитетов, эмоционально насыщенных сравнений и метафор, позволяющих создать образы, отвечающие идейно-художественному замыслу автора.

\section{Тувинская поэзия 1940-х годов}

22 июня 1941 г. на заседании 10-го Великого Хурала ТНР с гневным осуждением войны, начатой фашистской Германией, выступили С. Тока и С. Пюрбю (Салчак, 2000: 52). А 1 июля в газете «Шын»

${ }^{1}$ Идам-Сюрюн М. Шүлүктер [Стихотворения]. Кызыл: Тувинское книжное издательство, 1944. 62 с. С. 27-36.

(На тув. яз.). 
был напечатан текст выступления С. Пюрбю о задачах тувинской литературы в обстановке военного времени. Он утверждал, что:

«Поэзия должна поднимать патриотический дух народа и звучать как боевой клич. Призывать народ единым фронтом помогать Советской Армии в борьбе с врагом, отстоять свободу и независимость. Выражать непоколебимую веру в победу советского народа над проклятым фашизмом!» (НА ТИГПИ, д. 320, л. 21).

В годы Великой Отечественной войны советского народа против фашизма тувинские писатели своим призывом вдохновляли народ и отправлявшихся на фронт тувинских добровольцев. Их стихотворения, проникнутые патриотическим пафосом и несгибаемой верой в грядущую победу, тут же становились известны всему народу, их заучивали наизусть, читали вслух на собраниях и митингах.

Написанное в начале войны стихотворение С. Пюрбю «Тулчуушкунче!» («На битву!») 1941 г., выражая патриотические и интернациональные чувства бойцов, стало гимном тувинских добровольцев. Слова этой песни были созвучны сердцам сотен молодых людей, добровольно просивших отправить их на фронт. Песню пел весь народ - и стар, и млад:

Тулчуушкунче! Тулчуушкунче!

Тура душпейн, бурунгаар!
На битву! На битву!

Вперед, без оглядки вперед!

Эта песня имела такое же значение в Туве, как песня «Священная война» в СССР. А проникновенная баллада «Кызыл коъш» («Красный обоз») С. Пюрбю передавала чувство гордости людей за трудовой подъем, за то, что у них есть возможность помогать СССР в ее борьбе с фашизмом.

Гневным обвинением фашизма прозвучало стихотворение С. Сарыг-оола «Чылан сени» («Тебя гадюку») 1943 г., переложенного в музыку:

Чылан ышкаш хоран дылдыг

Чылбыганы Гитлерни

Чырык хүн дег совет чуртум

Чыжырт кылдыр чылча шавар.
Ядовитого, как змея, Коварного Гитлера

Насмерть растопчет

Советская солнечная страна.

Поэзия выражала неразрывную связь тувинского народа с фронтом, на который в 1943 г. отправились добровольцы ТНР. Одно за другим звучали стихи, написанные как поэтические письма тувинским добровольцам. Это стихи «Дайынчыга» («Бойцу») С. Пюрбю, «Танкиске чагыг» («Наказ танкисту»), «Кызыл Шеригде барган өңнүүмге» («Другу в Красной Армии») С. Сарыг-оола, «Майның белээ» («Майский подарок») Л. Чадамба, «Төрээн чурттуң патриотчуларынга» («Патриотам Родины») С. СамбаЛюндупа, «Хайыра чок сок-ла, эжим!» («Бей, друг, беспощадно!») И. Эргил-оола и т. д. Прекрасным художественным обобщением массового патриотического движения по сбору материальной помощи тувинцев фронту стала баллада С. Пюрбю «Красный обоз».

В эти годы поэтические произведения стали более дифференцированными. По сравнению с поэзией 1930-х годов уровень поэтического мастерства зачинателей литературы повысился, стали разнообразнее художественные средства. Например, стихотворение С. Пюрбю «Чалыы назынның кылажы» («Шествие юности») 1943 г. построено как призыв молодежи к борьбе, призыв закаляться, быть готовыми к любым напастям на пути строительства «светлого будущего».

Ярким явлением тувинской поэзии 1940-х годов стало издание Революционным Союзом молодежи сборника стихов «Calьь nazьnnьn kblazь» («Шествие юности», 1943), посвященного 25-летнему юбилею ленинско-сталинского комсомола. Книга маленького формата состоит из 29 стихотворений восьми авторов: Монгуша Идам-Сүрүна, Түлүша Пүрбү (Сергея Пюрбю), Агбаана Сарыг-оола (Степана Сарыгоола), Ондара Саган-оола (Олега Саган-оола), Чадамба, Эренчина, Нордупа, Биче-оола.

Книга открывается стихотворениями М. Идам-Сүрүна «Komsomol telgerezin!» («Да здравствует комсомол!») и Т. Пүрбү «Саlьь nazьnnьn kьlazь» («Шествие юности»), в которых мы отмечаем особый лиризм.

1 Calıь nazьnnьn kblazь [Шествие юности]. Kьzьl: Cogaal komitedi, 1943. 80 ap. (На тув. яз.). После перевода тувинской письменности в 1943 г. издания на яналифе продолжали выходить, переход издательских проектов на кириллицу был постепенным. 
Например, строки Идам-Сюрюна о комсомоле:

Өткүт ырда салгын куш дег ужуп

тур сен.

$* * *$

Талалихин, Таня, Фрунзе, Гастелло

วez,

Талантылар өзүп алыр кавай

болдуң.
В звонкой песне паришь, как

крылатая птица.

$* * *$

Ты колыбель, взращивающая

таланты,

Как Талалихин, Таня, Фрунзе,

Гастелло.

Рассмотрим два стихотворения Сергея Пюрбю с ярко выраженной метафорической образностью, выразительными сравнениями и идейно-эмоциональным пафосом:

В первом - «Чалыы назын делегерезин!» («Да здравствует юность!») (1943) - мотив грусти, возникающий в начале стихотворения, проходит через исторический экскурс поэта. В нем живыми красками обрисована жизнь молодого поколения в прошлом:
Кадарып-кадарып кээр,
Каткан кара моюн бээр.
Ишти-хырны куруг,
Идик-хеви самдар,
Чечек ышкаш чалыы назын
Черге калып, чидип чораан.
«Ийи экти кыстынган,
Ийи караа кылайган,
Билир чүвези чок,
Мирит ышкаш!» - диртип,
Хайыраан салым, чалыы назын
Хайыра чок хайлып чораан.
За тяжкий труд пастуха
Получая жесткое шейное мясо,
С пустым желудком,
В рваных обносках
В землю ложась, умирала
Цветущая юность.
Слушая, как обзывают
Ничего не знающим идиотом,
С вечно съежившимися плечами
И сверкающими (голодно) глазами,
Таяла безжалостно
Драгоценная юность.

В данных строках С. Пюрбю поэзия «предельно сближается с непосредственным и конкретным бытием человека, проникается его заботами, мыслями, чувствами, создается по его мерке...» (Аверинцев и др., 1994: 33).

А в следующем стихотворении «Эртенгиниң ыры» («Утренняя песня») - появление надежды на светлое будущее и вера в то, что молодежь не растеряет данную возможность, звучит призыв к позитивно значимым действиям в реальной жизни:

Эргим сарыым, чыргалаңзга базым немээр

$Э к и х ү н ү н$, чырык хүнүң үнүп олур.

\section{Моя дорогая, к блаженству} приближая на шаг,

Добрый твой день, светлый твой день уже настает.

Заканчивается стихотворение жизнеутверждающе. Поэт оказался прав в своем предвидении. И это предвидение коснулось не только социально-политических преобразований республики, но и того, что люди обрели веру в светлое будущее и что зародившаяся в 1930-е годы тувинская поэзия, движимая молодыми творческими силами, уверенно пойдет по пути дальнейшего развития. 
Таким образом, тувинская поэзия 1940-х годов, опираясь на народную поэзию и лучшие образцы русской поэзии, обрела свой неповторимый облик, заключающийся в национальной самобытности и гуманистическом пафосе в историческом контексте - пафосе борьбы за справедливость, светлое будущее и возвышение человека новой эпохи. В эти годы созданы крепкие основы гражданской, лирической и эпической поэзии.

\section{Заключение}

Создание в 1930 г. национальной письменности в ТНР способствовало зарождению тувинской художественной литературы и формированию литературного языка. В 1930-х годах печатались в основном стихотворения с отчетливо выраженной идеологической тенденциозностью. А с 1940-х годов тувинские поэты начали создавать патриотические и первые лирические стихотворения, воспевающие родной край, природу, любовь, вечные человеческие чувства и ценности.

Особое место в истории тувинской литературы занимает подвижнический труд основоположников тувинской поэзии: С. А. Сарыг-оола, С. Б. Пюрбю, М. Ы. Идам-Сюрюна, Б. Д. Ховенмея, Л. Б. Чадамба и других. Писатели ТНР стремились художественно обобщить глубинные изменения как в социальном, культурном развитии, так и нравственном облике строителей нового общества в связи с кардинальной переоценкой национально-культурных ценностей тувинского народа.

Тувинские авторы даже в условиях идеологических задач строительства нового социалистического общества стремились осмыслить и воспеть историческое прошлое, национальную самобытность и культурное наследие своего народа, обращая внимание на тонкие индивидуальные чувства и мысли тувинца. Особенно это характерно для раннего творчества Пюрбю и Идам-Сюрюна.

Взарождениитувинскойпоэзиисыгралиогромнуюрольпереводыстихотворений русскихи советских поэтов. Тувинские авторы, изучая их творчество, учились поэтическому мастерству, пониманию того, что творение поэзии есть умение искать и находить новые идеи и свежие оригинальные образы.

Несмотря на лозунговость и декларативность, первоначальные шаги тувинской поэзии в 1930-х годах послужили тем основанием, на котором впоследствии, в 1940-х годах, появились первые зрелые, знаковые произведения, ставшие классикой тувинской литературы: поэмы «Чечек» С. Пюрбю и «Саны-Мөге» С. Сарыг-оола. Это были поэтические произведения с философским осмыслением действительности, обобщением общественных явлений и процессов, а также проникнутые ярко выраженным лирическим чувством.

Таким образом, в период ТНР зачинатели литературного процесса за очень короткий отрезок времени заложили крепкий фундамент национальной литературы и определили подлинно гуманистическое направление для своих последователей.

\section{СПИСОК ЛИТЕРАТУРЫ}

Аверинцев, С. С., Андреев, М. Л., Гаспаров, М. Л., Гринцер, П. А., Михайлов, А. В. (1994) Категории поэтики в смене литературных эпох // Историческая поэтика. Литературные эпохи и типы художественного сознания : сборник статей / отв. ред. П. А. Гринцер. М. : Наследие. 512 с. С. 3-38.

История алтайской литературы (2004) : в 2-х кн. / рук. авт. колл. Р. А. Палкина. Горно-Алтайск : Юч-СумерБелуха. Кн. 1.552 с.

История бурятской литературы: 1917-1955 гг. (1995) : в 2-х ч. / под общ. ред. В. Ц. Найдакова. Улан-Удэ : БНЦ СО РАН. Ч. 1. Становление бурятской советской литературы (1917-1940). 256 с.

История тувинской литературы (2013) / отв. ред. К. А. Бичелдей. редкол.: Л. С. Мижит (рук. проекта) и др. Новосибирск : Изд-во СО РАН. Т. І. Истоки. Литература Тувинской Народной Республики (1921-1944). 266 с.

Калзан, А. К. (1980) Амыдырал болгаш литература: Тыва чогаал дугайында бодалдар [Жизнь и литература: Размышления о тувинской литературе]. Кызыл : Тувинское книжное издательство. 176 с.

Калзан, А. К. (2005) Общие тенденции развития языка тувинской литературы // Улуг-Хем. № 2. С. 128-136.

Куулар, Д. С. (1970) Тувинская поэзия: Очерк истории. Кызыл : Тувинское книжное издательство. 140 с.

Литература Якутии XX века: Историко-литературные очерки (2005) / редкол.: В. Н. Иванов (отв. ред.), П. В. Максимова, М. Н. Дьячковская, Л. Н. Романова. Якутск : Ин-т гуманит. исслед. АН РС(Я). 728 с. 
Михайлов, А. В. (2000) Обратный перевод. Русская и западно-европейская культура: проблемы взаимосвязей. М. : Языки русской культуры. 856 с.

Очерки истории хакасской советской литературы (1985) / отв. ред. К. Ф. Антошин. Абакан : Красноярское книжное издательство, Хакасское отделение. 288 с.

Салчак, В. С. (2000) Тыва чогаалчылар дугайында демдеглелдер [Заметки о писателях]. Кызыл : КЦО «Аныяк». 66 с. (На тув. яз.)

Танова, Е. Т. (2013) Тываның чогаалчылары: намдар төөгүзү, ажыл-чорудулгазы [Писатели Тувы: биографии и творческая деятельность] / ред. Л. С. Мижит. Кызыл : ОАО «Тываполиграф». 192 с. (На тув. яз.)

Татаринцев, Б. И. (2005) 75-летие создания тувинской национальной письменности // Гуманитарная наука Тувы на стыке веков: история, проблемы и перспективы: доклады научно-практической конференции, посвященной 75-летию тувинской письменности и 60-летию ТНИИЯЛИ-ТИГИ, 13-14 октября 2005 года / ред. А. А. Чернова. Кызыл : Типография КЦО «Аныяк». 135 с. С. 17-20.

Тыва литература: допчу төөгүзү [Тувинская литература: краткий очерк] (1964) / редкол. А. А. Пальмбах, Ю. Л. Аранчын, А. К. Калзан; ред. А. Чылбак-оол, А. Делгер-оол. Кызыл : Тувинское книжное издательство. 240 с. (На тув. яз.)

Тыва литератураның допчу очерги [Краткий очерк тувинской литературы] (1953) / авт. колл.: О. Саган-оол, Ю. Кюнзегеш, А. Мазуревская, Л. Гребнев. Ред. С. Сонам. Кызыл : Тувинское книжное издательство. 48 с. (На тув. яз.)

Тыва совет литератураның допчу төөгүзү [Очерки истории тувинской советской литературы] (1975) / А. К. Калзан, М. А. Хадаханэ, Д. С. Куулар. Кызыл : Тувинское книжное издательство. 332 с. (На тув. яз.)

Хализев, В. Е. (2009) Теория литературы. 5-е изд., испр. и доп. М. : Издательский центр «Академия». 432 с.

Дата поступления: 05.06.2020 г.

\section{REFERENCES}

Averintsev, S. S., Andreev, M. L., Gasparov, M. L., Grintser, P. A. and Mikhailov, A. V. (1994) Kategorii poetiki v smene literaturnykh epokh [Categories of poetics in the change of literary eras]. In: Istoricheskaia poetika. Literaturnye epokhi $i$ tipy khudozhestvennogo soznaniia [Historical poetics. Literary eras and types of artistic consciousness]: a collection of articles / ed. by P. A. Grintser. Moscow, Nasledie. 512 p. Pp. 3-38. (In Russ.).

Istoriia altaiskoi literatury [History of Altai literature] (2004) : in 2 books / ed. by R. A. Palkina. Gorno-Altaisk, IuchSumer-Belukha. Book 1. 552 p. (In Russ.).

Istoriia buriatskoi literatury: 1917-1955 gg. [The history of Buryat literature: 1917-1955] (1995) : in 2 parts / ed. by V. Ts. Naidakov. Ulan-Ude, BNTs SO RAN. Part 1. Stanovlenie buriatskoi sovetskoi literatury (1917-1940) [The formation of the Buryat Soviet literature (1917-1940)]. 256 p. (In Russ.).

Istoriia tuvinskoi literatury [A History of Tuvan Literature] (2013). Novosibirsk, Nauka. Vol. I. Istoki. Literatura Tuvinskoi Narodnoi Respubliki (1921-1944) [Literature of The People's Republic of Tuva (1921-1944)] / ed. by K. A. Bicheldei. Novosibirsk, SB RAS Publ. 266 p. (In Russ.).

Kalzan, A. K. (1980) Amydyral bolgash literatura: Tyva chogaal dugaiynda bodaldar [Life and literature: Reflections on Tuvan literature]. Kyzyl, Tuvan book publ. 176 p. (In Russ.).

Kalzan, A. K. (2005) Obshchie tendentsii razvitiia iazyka tuvinskoi literatury [General trends in the development of the language of Tuvan literature]. Ulug-Khem, no. 2, pp. 128-136. (In Russ.).

Kuular, D. S. (1970) Tuvinskaia poeziia: Ocherk istorii [Tuvan poetry: An essay on its history]. Kyzyl, Tuvan book publisher. 140 p. (In Russ.).

Literatura Yakutii XX veka: Istoriko-literaturnye ocherki [Literature of Yakutia of the XX century: Historical and literary essays] (2005) / editorial board V. N. Ivanov (ed.), P. V. Maksimova, M. N. D'iachkovskaia and L. N. Romanova. Yakutsk, In-t gumanit. issled. AN RS(Ia). 728 p. (In Russ.).

Mikhailov, A. V. (2000) Obratnyi perevod. Russkaia i zapadno-evropeiskaia kul'tura: problemy vzaimosviazei [Reverse translation. Russian and Western European cultures: problems of interrelation]. Moscow, Yazyki russkoi kul'tury. 856 p. (In Russ.).

Ocherki istorii khakasskoi sovetskoi literatury [Essays on the history of Khakass Soviet literature] (1985) / ed. by K. F. Antoshin. Abakan, Krasnoyarsk book publishing house, Khakass branch. 288 p. (In Russ.).

Salchak, V. S. (2000) Tyva chogaalchylar dugaiynda demdeglelder [Notes on the writers]. Kyzyl, KTsO “Anyiak”. 66 p. (In Tuv.) 
Tanova, E. T. (2013) Tyvanyng chogaalchylary: namdar töögüzü, azhyl-chorudulgazy [Writers of Tuva: biographies and creative activities] / ed. by L. S. Mizhit. Kyzyl, OAO «Tyvapoligraf». 192 p. (In Tuv.)

Tatarintsev, B. I. (2005) 75-letie sozdaniia tuvinskoi natsional'noi pis'mennosti [75th anniversary of the creation of the Tuva national writing system]. In: Gumanitarnaia nauka Tuvy na styke vekov: istoriia, problemy i perspektivy [The Humanities in Tuva at the Turn of the Century: History, Problems and Prospects]; Proceedings of the conference dedicated to the $75^{\text {th }}$ anniversary of Tuvan writing and the 60th anniversary of TNIIYALI-TIGI, October 13-14, 2005 / ed. by A. A. Chernova. Kyzyl, Tipografiia KTsO «Anyiak». 135 p. Pp. 17-20. (In Russ.).

Tyva literatura: dopchu töögüzü [Tuvan literature: a brief essay] (1964) / editorial board A. A. Pal'mbakh, Yu. L. Aranchyn and A. K. Kalzan; ed. by A. Chylbak-ool and A. Delger-ool. Kyzyl, Tuvan book publisher. 240 p. (In Tuv.)

Tyva literaturanyng dopchu ochergi [A brief essay of Tuvan literature] (1953)/ O. Sagan-ool, Yu. Kunzegesh, A. Mazurevskaia and L. Grebnev, ed. by S. Sonam. Kyzyl, Tuvan book publisher. 48 p. (In Tuv.)

Tyva sovet literaturanyng dopchu töögüzü [Essays on the history of Tuvan Soviet literature] (1975) / A. K. Kalzan, M. A. Khadakhane and D. S. Kuular. Kyzyl, Tuvan book publisher. 332 p. (In Tuv.)

Khalizev, V. E. (2009) Teoriia literatury [Theory of literature]. $5^{\text {th }}$ edn. Moscow, Akademiia. 432 p. (In Russ.).

Submission date: 05.06.2020. 